\title{
Retrofitting existing buildings to reduce electrical energy consumption and greenhouse gas emission in Nigerian food and beverage industries
}

Ayodeji Samson Ogunjuyigbe, Temitope Raphael Ayodele* and Segun Monsur Ogunmuyiwa

${ }^{*}$ Correspondence:

a.ogunjuyigbe@ui.edu.ng;

tayodele2001@yahoo.com;

tr.ayodele@ui.edu.ng

Power Energy Machine and Drive (PEMD)

Research Group, Electrical and Electronic Engineering Department, Faculty

of Technology, University of Ibadan, Ibadan, Nigeria

\begin{abstract}
Food and Beverage industry is one of the fastest growing manufacturing industries in Nigeria with its attendant carbon emission. In this paper, retrofitting (one of the demand side management (DSM) techniques) is adopted as a strategy to reducing energy consumption and the associated greenhouse gas emission of three selected food and beverages industries in Nigeria. This is achieved by carrying out a walk through energy audit on the selected industries with the aim of reducing their carbon footprint by reducing the electrical energy consumption pattern. Retrofitting exercise involves identification of energy-inefficient electrical equipment within the industry and thereafter replacing them with available identical device but with better energy efficiency. The investment cost for adopting energy efficient technology and its corresponding payback period are estimated. Recommendations for policy documents were proposed based on the study. The energy audit reveals that electric motor, lighting points (lamps) and computer system constitute electrical load that are inefficiently operated within the selected industries. Applying DSM by retrofitting on these components of electrical load reduces the overall electrical energy consumption of the industry by $17 \%, 20 \%$ and $14 \%$ for industries A, B and C, respectively. An estimated reduction in $\mathrm{CO}_{2}$ emission of $159,471.2 \mathrm{~kg}, 139,598.7 \mathrm{~kg}$ and $186,696.4 \mathrm{~kg}$ is achieved for industries A, B and C, respectively, using the DSM. This paper is useful as it provides scientific information on the need to retrofit inefficient devices in Nigeria industries.
\end{abstract}

Keywords: Demand side management, GHGs emission, Energy audit, Energy efficiency, Food and beverage industry, Retrifiting

\section{Introduction}

In recent years, there have been efforts to reduce greenhouse gas (GHG) emission in order to mitigate the effects of climate change on the environment $[3,16]$. There are basically two identified means of achieving this: through the reduction in energy consumption by means of energy efficiency strategy and by ultilizing renewable energy sources as part of generational mix [28]. Presently, world energy growth stands at $1.6 \%$ rate per annum, and this is expected to increase the world energy demand by $50 \%$ by 2030 [5]. As the energy demand increases, so also the GHG emission increases [11]. Most of this

(C) The Author(s) 2020. This article is licensed under a Creative Commons Attribution 4.0 International License, which permits use, sharing, adaptation, distribution and reproduction in any medium or format, as long as you give appropriate credit to the original author(s) and the source, provide a link to the Creative Commons licence, and indicate if changes were made. The images or other third party material in this article are included in the article's Creative Commons licence, unless indicated otherwise in a credit line to the material. If material is not included in the article's Creative Commons licence and your intended use is not permitted by statutory regulation or exceeds the permitted use, you will need to obtain permission directly from the copyright holder. To view a copy of this licence, visit http://creativeco mmons.org/licenses/by/4.0/. 
increase may likely come from the developing nations as a result of increasing population and expansion in economic growth [36]. It has been estimated that industrial sector account for $54 \%$ of the total world energy consumption [9]. Hence, a cut down on the energy consumption from this sector will reduce the overall energy demand and by extension reduces the GHG emission [20]. Of the various industrial energy demands, electrical energy is significant [8] as it is required to achieve nearly all the industrial processes.

Demand side management (DSM) is the implementation of strategies which tend to control, influence and eventually cut down on energy consumption with the aim of lowering energy costs and bring immediate benefits to an organization or enterprise [29]. Implementation of DSM is more profitable than investing in new generating capacity. From an environmental point of view, improved efficiency reduces the GHG emission into the atmosphere, thereby promoting sustainable environment. Some of the benefits of DSM include reduction in energy bills, reduction in the need for new power plant, improvement transmission and distribution networks, stimulation of economic development, creation of long-term jobs due to new innovations and technologies, increased competition among local enterprises, reduction in pollutions, reduction of dependency on foreign energy sources and reductions in peak power prices for electricity [34]. For the industries, DSM translates into lower production cost and more competitive products. Industrial plants are often able to reduce overall demand by adopting various kinds of energy efficiency measures. Many DSM measures are put in place by utilities or by energy end-users themselves especially the industrial sectors. Demand schedule are sometimes altered to allow industries to move the demand away from peak periods, thereby cutting down on cost. In some cases, there are penalties charged on industries for operating inefficient equipment with unnecessary high loads. This tends to encourage industries to upgrade their equipment so as to reduce electrical demands. A straightforward reduction in energy consumption will normally reduce costs, and a shift of demand to a different time might also reduce costs if an appropriate tariff is available [25]. The main types of DSM activities may be classified into three categories: the energy-saving programs (i.e. reducing the demand through the use of efficient processes), load management programs (i.e. shifting the load pattern and encourage reduction in demand at peak times and peak rates) and load growth and conservation programs. In this study, energy-saving program is adopted.

Literature reveals that many attempts have been made to achieve energy saving via exploitation of various energy management strategies. For example, Khan explored the potentiality of energy-saving behaviour as a DSM strategy for energy management in developing economy. The author revealed that energy-saving behaviour could reduce energy demand by about 21.9\% [18]. Aghajani and Ghadimi were of the opinion that the main issue to pay attention in energy management are the operation cost and pollution rate [1]. In achieving this, power converters and energy management algorithm (EMA) are useful means of providing essential control to the power system in order to improve energy efficiency, thereby reducing GHG emission and saving cost [13]. Similarly, Walzberg et al. believed that demand side management should be viewed from the socio-technical perspective in order to minimize errors [37]. This strategy would ensure that social optimum as well as the technological optimum is taken into consideration in 
the selection of technology by the users. In general, DSM has been adjudged an effective means of ensuring grid reliability and reduces operational costs for the utility operators, while reducing electricity costs for the consumers [22]. The developed nations are adopting smart grid technologies to better implement DSM strategies [10]; however, many developing world especially the African nation are struggling with smart technologies, thereby resulting into retrofitting and behavioural change as a means of DSM strategies. Retrofitting existing building can be seen as an efficient and cost-effective way of achieving energy conservation and reducing greenhouse gas emissions [2]. It reduces energy consumption and reduces the cost of heating, cooling and lighting. The general goal of retrofitting is to create a high-performance building by applying integrated, whole building design process with the objective of reducing the overall operational cost, decreasing environmental impact, improving building adaptability, reliability, durability and resiliency [31]. Radwan et al. [32] performed retrofitting exercise as a means of DSM in an hospital in Egypt, with the aim of achieving efficient energy saving that would decrease the energy consumption and reduces HVAC system in the hospital. The new retrofitted fittings that were selected according to the new hospital cooling loads were compared against the existing system, and significant energy saving of 7,068,178 kW h/year was achieved. In another work, Luther and Rajagopalan identified the challenges faced in decision making process during energy retrofitting of an existing building [19]. The authors highlighted the methodology required to achieve a successful retrofitting exercise. First, efforts are centred on identifying energy waste through integrity audit; next overall peak electrical demand is reduced by retrofitting existing devices for energy efficiency purpose.

In Nigeria, the industrial sector is the main consumer of electricity and it accounts for about $45 \%$ of the total electrical energy consumption in the country [15]. The sector has contributed greatly to the economic growth with gross domestic product (GDP) of about 7.23 billion Naira representing about 9\% of real GDP in 2013 [23]. Of the different industries that make up the industrial sector, the Nigerian food and beverage industry (NFBI) accounts for $35 \%$ of the composition of the sector in the country making it one of the industries with highest demand of electricity in the country [27]. The industry also engages $10.46 \%$ of the total workforce of the industrial sector making it one of the largest industry in the country [23]. The industry relies on two electrical energy sources for its industrial processes: electrical power from the national grid and the use of diesel generating sets as back up [4]. However, the inadequate power supply in recent times has resulted in the frequent use of diesel generators. This contributes to the GHG emission with its attendant environmental risk such as pollution and climate change.

One of the cheapest ways to arrest this challenge is to reduce the energy consumption through the use of energy efficiency devices option without compromising the production processes [7]. This will in turn reduce the fuel consumption, thereby cutting down on the GHG emission [6, 24, 28]. The option has the advantages of reducing the energy bills and offset the carbon content in the atmosphere, which will result in health benefits and also mitigate GHG emission. This paper therefore employs retrofitting technique as a DSM tool to reducing electrical energy consumption and the associated GHG emission in 3 selected Nigerian food and beverage industries. The retrofitting exercise identifies inefficient electrical device within the selected industries and replaces them with 
improved energy-efficient devices. The main aim of the study is to evaluate the technical, economic and environmental benefits $\left(\mathrm{CO}_{2}\right.$ emissions) of applying DSM solution using retrofitting techniques. Also, the energy consumption before and after the application of DSM is compared to ascertain the benefit of DSM to Nigerian food and beverage industry. The remaining part of the paper is organized as follows: "DSM opportunities in Nigerian food and beverage industries" section presents the DSM opportunity in the Nigerian food and beverage industries, "Material and method" section highlights the methodology adopted in achieving the set objective, "Result and discussion" section discusses the results obtained, "Policy recommendation based on the study" section presents the policy recommendation based on the study while the conclusion of the study is provided in "Conclusions" section.

\section{DSM opportunities in Nigerian food and beverage industries}

There are many companies constituting the food and beverage industry. However, three companies from the sector are selected for study as it is impractical to perform study on all the companies considering their numerous numbers in the country. The selections are based on the company with highest number of industrial plant in the country; therefore, the first three companies with the highest number of industrial plants are selected and are designated as A, B and C, respectively. All the industrial plants are similar in production processes and in capacity. It is believed that a successful study on one can be replicated in other industrial plants across the country; hence, the study is based on industrial plant of each of the three companies located in Ibadan, South West Nigeria.

\section{Energy audit}

Energy audit is an exercise that helps to determine the emissions, energy consumptions and production levels over a period of time from historical records and thereafter identifies areas where energy consumption can be minimized [14]. Therefore, energy audit can be seen as a systematic approach for decision making in energy management. The exercise was conducted for the three selected food and beverage industries. This involved the identification of all power consuming devices and appliances within the industry and counting the number of each device/appliance thus forming a comprehensive list of all devices/appliances used within the industry. The rating of each device/appliance was read out and recorded from the nameplate, while the hours of operation were also obtained from the operation Engineer/Manager of the corresponding factory by interview. From the energy audit, the daily and monthly load profiles for each of the industry were obtained and are depicted in Figs. 1 and 2. The industry is running a shift (time when another set of workers resume duty), and it is between hour 5 and 6 . However, the workers are allowed to take a rest between the hours of 23 and 24. At these two periods, production processes are short down. This is what is responsible for the low energy consumption between those periods in Fig. 1. It can be observed from the two figures that the industries have similar shapes of load profiles. This is expected as the industries have similar production processes. However, industry A is relatively smaller compared to industries $B$ and $C$. This also reflects in the daily and monthly electrical energy requirements of the industries. Figure 2 shows that electrical energy consumption is nearly zero 


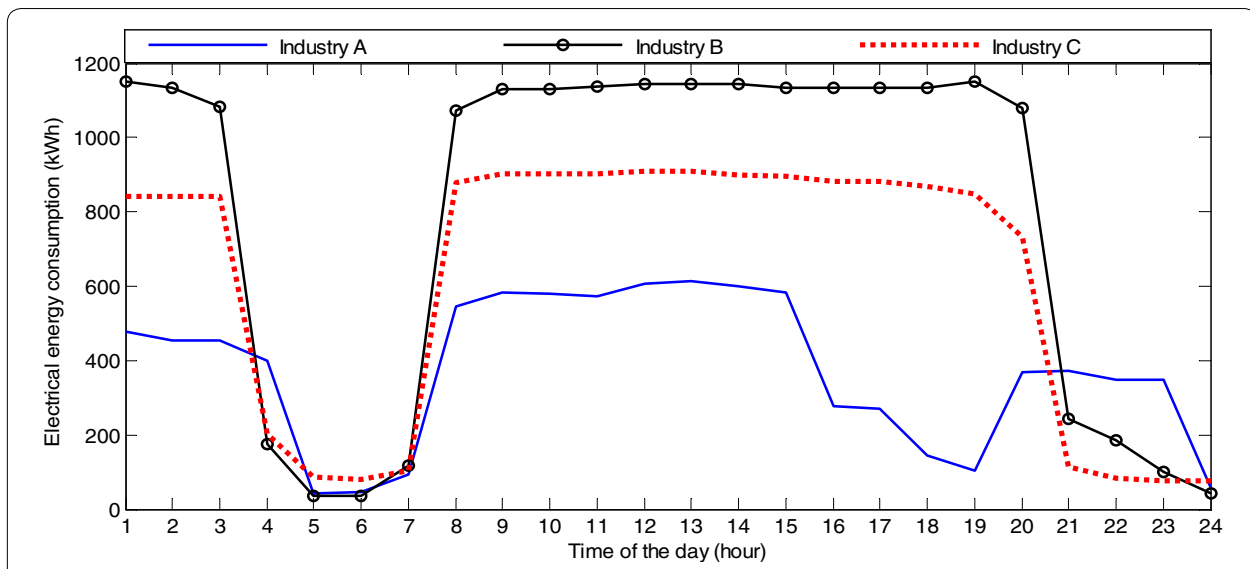

Fig. 1 Daily load profile for the industries

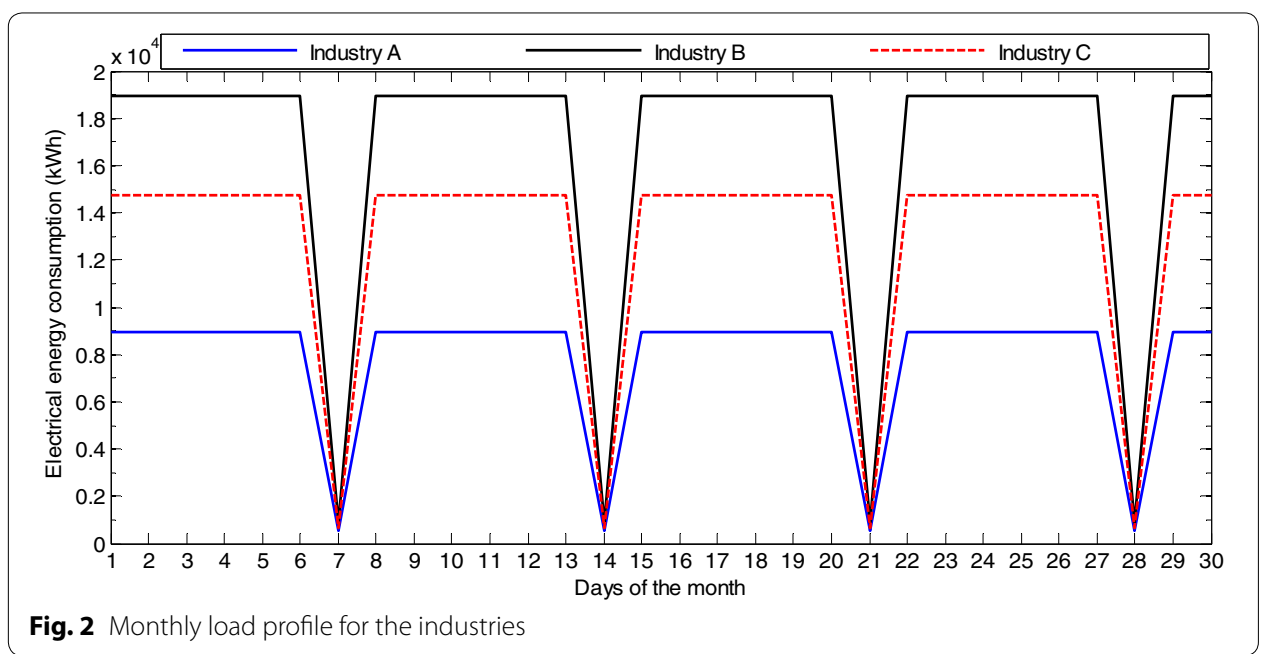

on days 7, 14, 21 and 28. This is also expected as these days fall on Sundays when no production activities are going on in the industries.

The total loads in each of the industry were classified into five classes in order to simplify the complexity of the analysis. The classification is as follows: (1) lightings, (2) cooling appliances, (3) office and computer system, (4) heating appliances and (5) electric motors. The items (electrical appliances) which are contained in each class are depicted in Table 1. The estimation of electrical energy consumption by class is depicted in Table 2. The table reveals that the appliances belonging to electric motor class consume the highest electrical energy. This is further elucidated in Fig. 3. After the load audit exercise, it was identified that there are potential saving opportunity on electric motors, lighting and office (i.e. computer system).

\section{Energy-saving opportunities on electric motors}

Motors are significant energy-consuming devices in the food and beverage industry. During the audit exercise, motors and drives system account for bulk of electric energy consumption in industries A, B and C with 70,78 and $77 \%$ of the total 
Table 1 Classification of electrical items within the industries

\begin{tabular}{|c|c|c|c|c|c|}
\hline Class & Item & Class & Item & Class & Item \\
\hline \multirow[t]{6}{*}{ Lighting } & $\begin{array}{l}\text { Factory flores- } \\
\text { cent }\end{array}$ & \multirow[t]{7}{*}{$\begin{array}{l}\text { Office and com- } \\
\text { puter system }\end{array}$} & $\begin{array}{l}\text { Computer } \\
\text { CPU + Monitor }\end{array}$ & \multirow[t]{10}{*}{ Electric motors } & Conveyor \\
\hline & Office florescent & & Telephone & & Bottler filler \\
\hline & $\begin{array}{l}\text { Exterior flores- } \\
\text { cent }\end{array}$ & & TV and decoder & & Mixer \\
\hline & $\begin{array}{l}\text { Toilet, corridor } \\
\text { incandescent }\end{array}$ & & Printer & & Bottler washer \\
\hline & $\begin{array}{l}\text { Security-halo- } \\
\text { gen }\end{array}$ & & Photocopier & & Unscramble loader \\
\hline & $\begin{array}{l}\text { Factory, inte- } \\
\text { rior-other }\end{array}$ & & $\begin{array}{l}\text { Money-counting } \\
\text { machine }\end{array}$ & & Case parker \\
\hline \multirow{4}{*}{$\begin{array}{l}\text { Cooling appli- } \\
\text { ances }\end{array}$} & Fan & & Radio & & Uncase machine \\
\hline & $A C$ & \multirow{3}{*}{$\begin{array}{l}\text { Heating appli- } \\
\text { ances }\end{array}$} & Boiler & & Exterior-E-Motor \\
\hline & Refrigerator & & Water heater & & Pumps \\
\hline & Water dispenser & & Electric Kettle & & Compressor \\
\hline
\end{tabular}

Table 2 Estimated electrical energy consumption by load class obtained through energy audit (kW h)

\begin{tabular}{lllrl}
\hline S/N & Load classification & \multicolumn{2}{l}{ Industries } & \\
\cline { 3 - 5 } & & Industry A & Industry B & Industry C \\
\hline 1. & Electric motor & 6323 & 14,882 & 11,297 \\
2. & Lighting & 675 & 788 & 606 \\
3. & Heating & 745 & 1698 & 1621 \\
4. & Cooling & 991 & 1473 & 945 \\
5. & Office equipment & 342 & 132 & 279 \\
6. & Total & 9076 & 18,973 & 11,297 \\
\hline
\end{tabular}

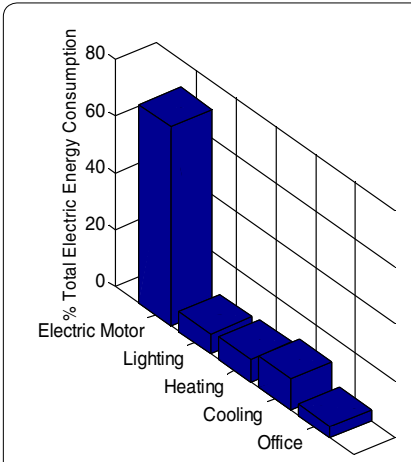

Load Classification for Industry A a

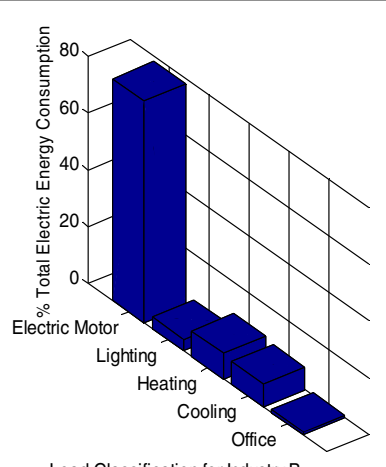

Load Classification for Industry B b

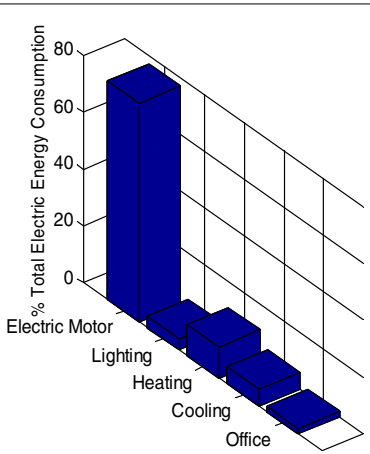

Load Classification for Industry C

C

Fig. 3 Classification of loads by electricity consumption in a industry A, b industry B, c industry C

electricity consumption, respectively. Most of the production processes of the industries depend heavily on electric motors for grinding, pumps, conveyors and compressors. Implementing high efficient motors can be achieved by reducing losses through the use of improved steel properties, increase in conductor volume, lowering the 
resistance of winding, narrowing the air gap and bettering aerodynamics design of the motor. Poor motor performance is a major source of energy losses. During the audit exercise, it was observed that all motors rated $5 \mathrm{~kW}$ and above have lower operating efficiency and are not International Electrotechnical Commission (IEC) compliant. It was also observed that some of the motors have been rewound which further reduces the efficiency of the motors [26].

In order to reduce energy consumption on electric motors, a retrofitting demand side management is proposed where the inefficient motors are replaced with equivalent high performance energy-efficient motors. This was achieved using EuroDEEM simulation software. The software is an industrial motor energy management tool developed by Washington State University (WSU). It helps to find energy-efficient alternative to existing electric motor. The energy saving as a result of the replacement was calculated, and the payback period to offset the investment in the practice was determined.

\section{Energy-saving opportunities on lighting and computer systems}

Lightings account for the 7, 4 and $4 \%$, respectively, of the total electrical energy consumption in the industries. Lighting system offers good opportunities for savings in the industry. The audit exercise reveals that incandescent, fluorescent and halogen lamps were commonly used. These lighting devices are inefficient and could be upgraded to reduce energy consumption. A retrofitting exercise is proposed to replace the inefficient lamps with the efficient LED tubes, CFLs, LED flood light and other low energy light sources without reducing the required light intensity.

However, the computer system represents 4,1 and $2 \%$ of the total electrical energy consumption within the industries, respectively. However, during the energy audit, it was also observed that energy-saving opportunity exists with the computer system. The industries are currently using desktop computers which comprises of monitor (cathode ray tube) and CPU. Hence, an upgrade of the computer system to a flat screen system or laptop computer will save a lot of electrical energy. The investment cost in carrying out the retrofitting exercise, the payback period and the light intensity after replacement are determined to ascertain the benefit of employing energy-efficient devices.

\section{Material and method}

The designed calculation for determining the cost of electrical energy consumption, the energy saving from retrofitting exercise, the cost of energy saved, the payback period and the amount of $\mathrm{CO}_{2}$ emission saved from the retrofitting exercise is presented in this section.

\section{Electric motor}

The use of standard electric motors represents a source of significant energy waste in the Nigeria food and beverage industries. In view of this, equivalent commercially available electric motor having the same power rating, phase input, rotational speed operating voltage but with higher efficiency was sought to replace each of the existing electric motor in each of the industry. Energy consumption used by the electric motor can be evaluated using: 


$$
E=\frac{\mathrm{hp} \times L \times 0.746 \times H_{\mathrm{op}} \times 100}{\eta}
$$

Cost of energy used by the electric motor can by evaluated as:

$$
C_{\mathrm{E}}=\frac{\mathrm{hp} \times L \times 0.746 \times H_{\mathrm{op}} \times C_{\mathrm{u}} \times 100}{\eta}
$$

The cost of energy saved after retrofitting can be obtained as:

$$
\mathrm{COE}_{\text {savings }}=\mathrm{hp} \times L \times 0.746 \times H_{\mathrm{op}} \times C_{\mathrm{u}}\left(\frac{100}{\eta_{\text {old }}}-\frac{100}{\eta_{\text {new }}}\right)
$$

where $E$ is the energy consumption by the electric motor, hp is the motor rated horsepower, $L$ is the load factor (percentage of full load/100), $H_{\mathrm{op}}$ is the operating hours, $\eta$ is the motor efficiency, the conversion from horsepower to $\mathrm{kW}$ unit is taking as $0.746, C_{\mathrm{u}}$ is the unit energy costs $(\$ / \mathrm{kW} \mathrm{h}), \eta_{\text {old }}$ is the efficiency of old existing motor and $\eta_{\text {new }}$ is the efficiency of new motor.

For new motor purchase, the payback period (in months) is the premium price (PP) minus any utility rebate (UR) for energy-efficient motors, divided by the total annual dollar savings (AS) and can be calculated as:

$$
\text { Payback (in months) }=\left(\frac{\mathrm{PP}-\mathrm{UR}}{\mathrm{AS}(\$)}\right) \times 12
$$

Also, the payback for replacing an operating old motor is calculated using the full purchase price as well as the installation cost (IC) as expressed by:

$$
\text { Payback (in months) }=\left(\frac{\mathrm{PP}+\mathrm{IC}-\mathrm{UR}}{\mathrm{AS}(\$)}\right) \times 12
$$

\section{Lighting and computer system}

The cost of energy saved as a result of lighting and computer system can be determined as:

$$
C_{\text {es }}=N_{\mathrm{r}}\left(W_{\text {old }}-W_{\text {new }}\right) \times T
$$

where $C_{\mathrm{es}}$ is the cost of energy saved per annum, $N_{r}$ is the number of lamp/computer retrofits, $T$ operating hours per annum, $W_{\text {old }}$ is wattage of existing lamp/computer system, $W_{\text {new }}$ is the wattage of the replaced lamp/computer system.

\section{Modelling of green house gases emission}

Greenhouse gases (GHGs) trap and hold the heat in the atmosphere; by so doing, the heat present in the atmosphere increases, which leads to global warming. The most significant GHGs are water vapour $\left(\mathrm{H}_{2} \mathrm{O}\right)$, methane $\left(\mathrm{CH}_{4}\right)$, carbon dioxide $\left(\mathrm{CO}_{2}\right)$ and nitrous oxide $\left(\mathrm{N}_{2} \mathrm{O}\right)$. Of this various components of GHGs, carbon dioxide $\left(\mathrm{CO}_{2}\right)$ is found to be the most significant in heat trapping due to its increasing concentration in the atmosphere [30]. Therefore, emphasis is laid on $\mathrm{CO}_{2}$ reduction. Nigeria food and beverage industries rely on two major sources of electricity, i.e. electricity from the 
national grid and diesel generating set. However, due to the present epileptic power supply, most of the companies rely on diesel generators for production processes. One of the ways to reduce $\mathrm{CO}_{2}$ is by reducing the amount of diesel to be burnt. This can be achieved by cutting down on energy consumption through the use of energy-efficient devices.

The total GHG emission as a result of production process in the company can be determined as:

$$
\mathrm{EM}_{\text {total }}=\mathrm{EM}_{\text {electricity }}+\mathrm{EM}_{\text {diesel }}
$$

The emission from each electrical energy source can be evaluated as (8) and (9).

$$
\begin{aligned}
& \mathrm{EM}_{\text {electricity.consumption }}=\mathrm{GE}[\mathrm{kW} \mathrm{h} / \mathrm{yr}] \times \mathrm{EF}_{\text {reg }}\left[\mathrm{kgCO}_{2} / \mathrm{kw} \mathrm{h}\right] \\
& \mathrm{EM}_{\text {diesel.consumption }}=D[L / \mathrm{yr}] * \mathrm{EF}_{\text {diesel }}\left[\mathrm{kgCO}_{2} / \mathrm{L}\right]
\end{aligned}
$$

where GE is the total electricity consumption from the grid ( $\mathrm{kW} \mathrm{h} / \mathrm{yr}), E F_{\text {reg }}$ is the $\mathrm{CO}_{2}$ emission factor for regional electricity $\left[\mathrm{kg} \mathrm{CO}_{2}\right]$ and it varies from region to region, $D$ is the annual diesel consumption (L/yr), $E F_{\text {diesel }}$ is the emission factor for diesel fuel $[\mathrm{kg}$ $\mathrm{CO}_{2}$ ]. The emission factors are obtained from International Sustainability and Carbon Certification [17].

\section{Result and discussion}

This section discusses the results of electric motors retrofitting exercise in each of the three industries and bringing out the effects of energy management before and after the retrofitting exercise. It also discusses the investment involved in the retrofitting exercise.

\section{Electric motors}

One of the ways to improve the overall efficiency of energy consumption in the industry is by replacing the low efficient motor with a high efficient one [12, 21, 33], 35]. To achieve this, a retrofitting exercise was performed for each of the three companies by identifying and replacing the existing low efficient standard motors with super-efficient ones. In doing this, it was ensured that the new motors were of the same equivalent ratings as the old one (i.e. the same power rating, operating voltage and rotational speed) but with higher efficiency. The cost of replacing the individual existing motors (\$), the energy saved by replacing old inefficient motors with super-efficient one $(\mathrm{kW} \mathrm{h} / \mathrm{yr})$ and the payback period on each type of electric motors to recoup the investment on each type of motors were calculated for each of the companies (A, B \& C), and the results are depicted in Tables 3, 4 and 5, respectively.

The tables reveal that the money invested in the retrofitting exercise can be recovered within an average period of 3 years for most of the electric motors in the industries. The differences in energy consumption for each of the three companies as a result of replacement of inefficient motors with the super-efficient one are depicted in Fig. 4. The figure reveals that there is a considerable difference in the energy consumption before DSM (retrofitting exercise) was applied and after the application of DSM. The overall investments and savings in electric motor for each of the industries are presented in Table 6. It 


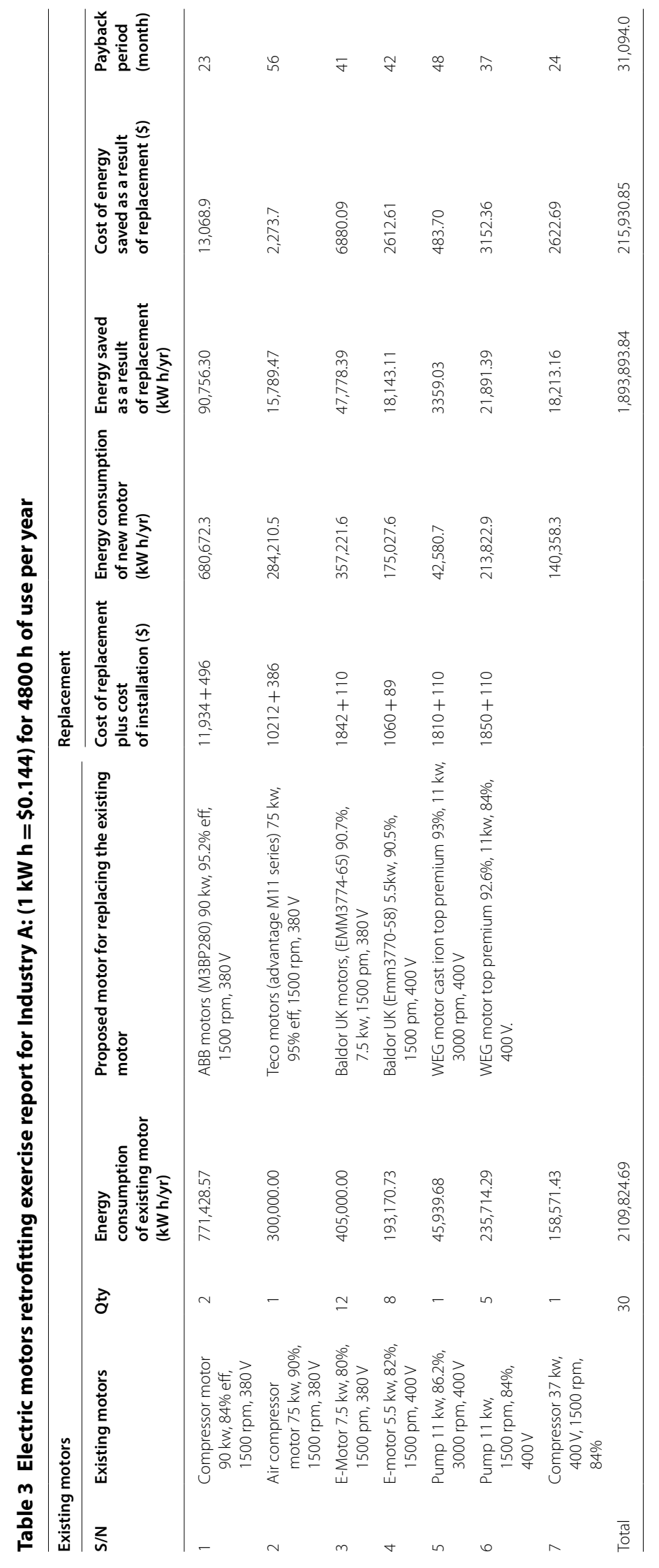




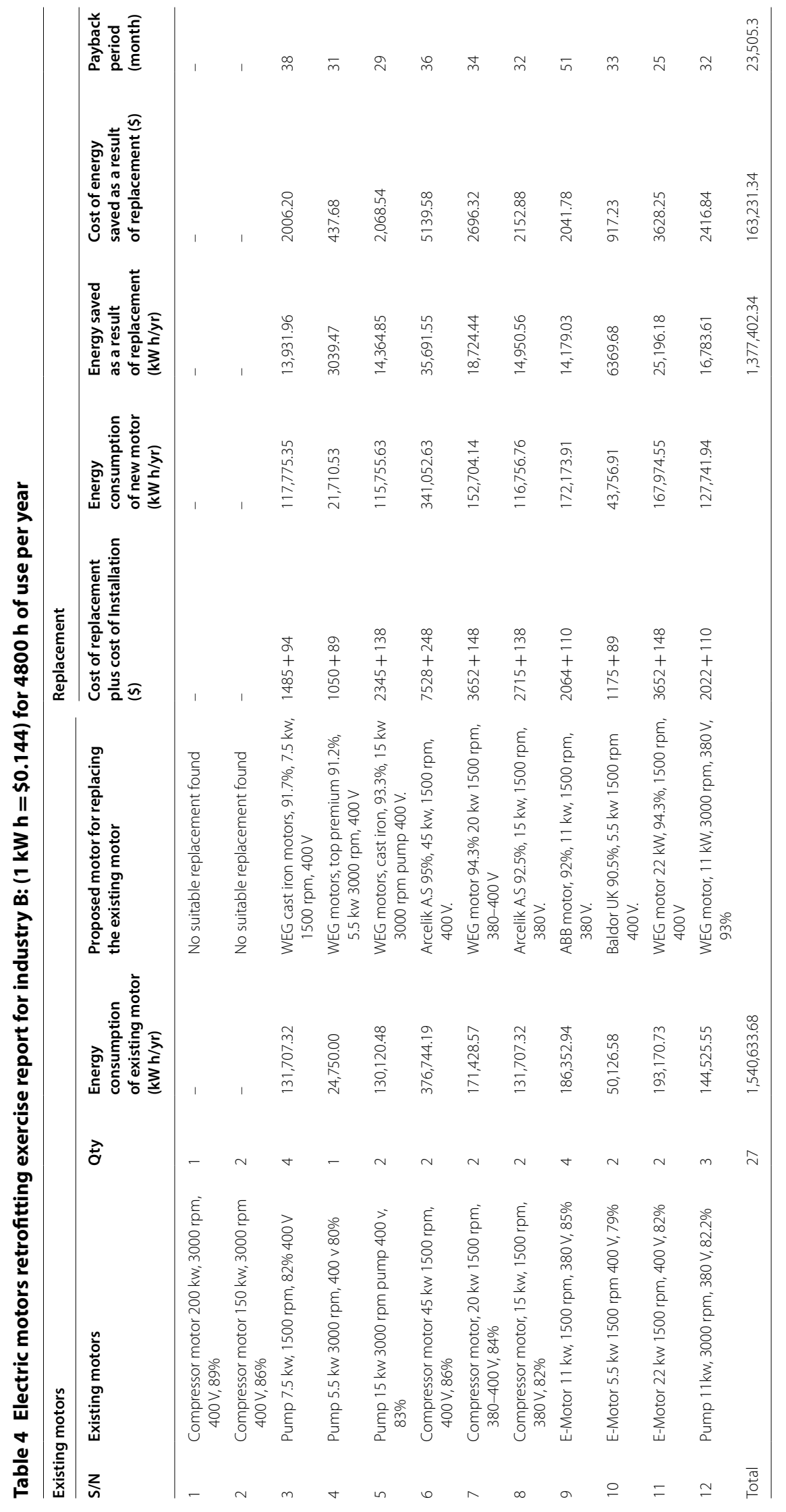




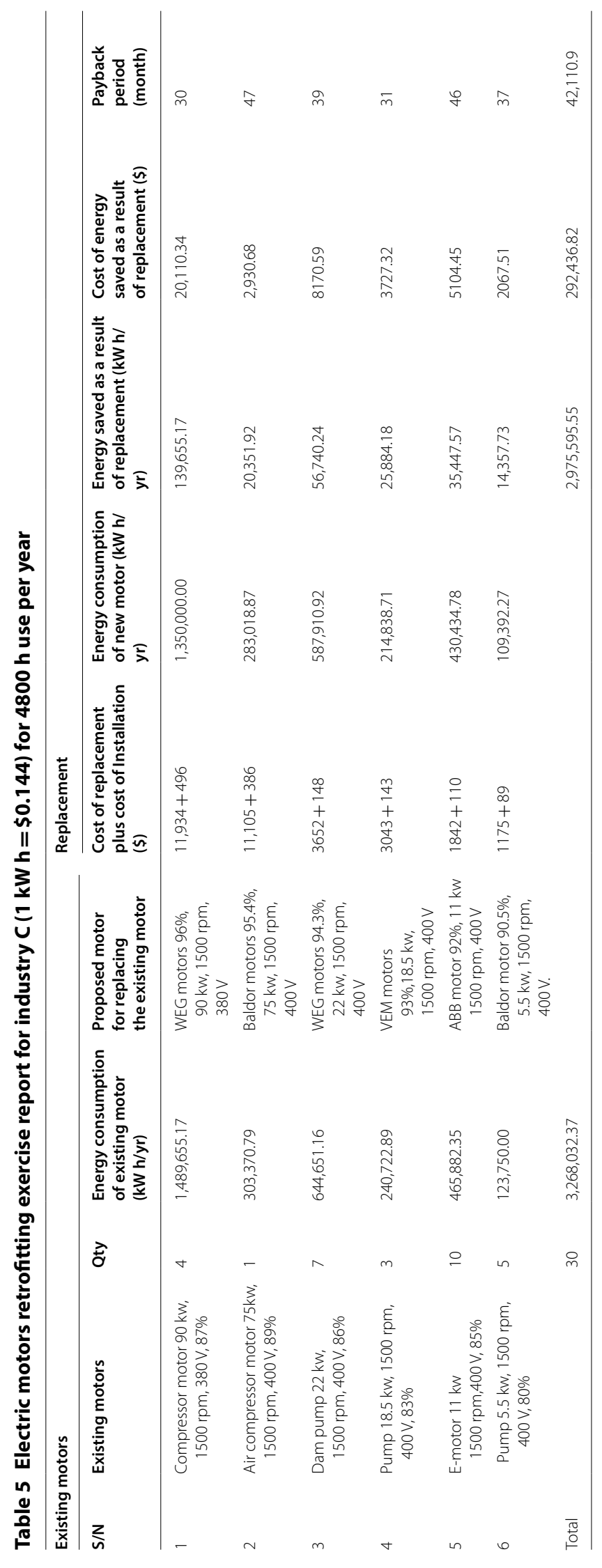




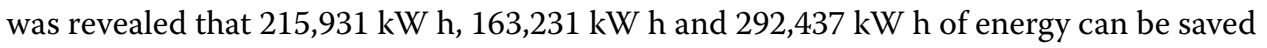
per annum in industries A, B and C, respectively. This will amount to $\$ 31,094, \$ 23,505$ and $\$ 42,111$ reduction in electricity bill per annum with a payback time of 34,36 and 35 months, respectively.

\section{Lighting fixtures}

Energy-saving opportunity was also identified in lighting fixtures. The use of energyefficient lighting fixtures will result into energy savings in the industries. Retrofitting was proposed for each of the fixtures in each of the industry. The existing lighting fixtures and their luminous intensity, the proposed fixture to replace the existing ones and their luminous intensity, the calculated energy consumption before and after the retrofitting exercise would have been performed, and the saving in energy for each of the three industries are depicted in Table 7.

The overall annual energy savings, cost of investment and payback time arising from the upgrade were determined, and the result is presented in Table 8. The table revealed that the $133,680 \mathrm{~kW} h, 161,160 \mathrm{~kW}$ h and $120,474 \mathrm{~kW}$ h of energy can be saved per annum in industries A, B and C, respectively. This will amount to $\$ 19,250$, $\$ 23,207$ and $\$ 17,348$ reduction in electricity bill per annum with a payback time of 12 , 11 and 12 months, respectively.

\section{Computer system}

The result of the walk through audit also revealed that performing retrofitting exercise in each of the industries computer system will bring reduction in energy consumption and hence save electricity bill. The audit reveals that cathode ray tube monitor and CPU with energy consumption of $300 \mathrm{~W}$ are still in use in these industries. Replacement of the old computer system with $65 \mathrm{~W}$ laptop is proposed as a DSM solution. The energy consumption before and after the proposed DSM solution as well as the energy saved are depicted Table 9. It was revealed that 45,120 kW h, 21,150 kW h and $49,205 \mathrm{~kW}$ h of energy can be saved per annum in industries A, B and C, respectively.

Obviously, replacing existing computer systems with laptop computers will reduce the electricity bill. The total investment in replacing these existing computer systems, savings (\$) on energy as a result of DSM solution and the payback period arising from the upgrade are presented in Table 10. A total reduction in electricity bill by $\$ 49,205, \$ 3046$ and $\$ 7086$ can be achieved per annum with a payback time of 56,37 and 46 months, respectively.

\section{Comparison of load profile before and after the DSM solution}

The load profile of electricity consumption of the industries was determined and compared before and after the proposed application of DSM. The results are depicted in Figs. 5, 6 and 7.

From the figures, it can be observed that the retrofitting exercise allows a shift in the energy profile indicating reduction in energy consumptions for the industries. 


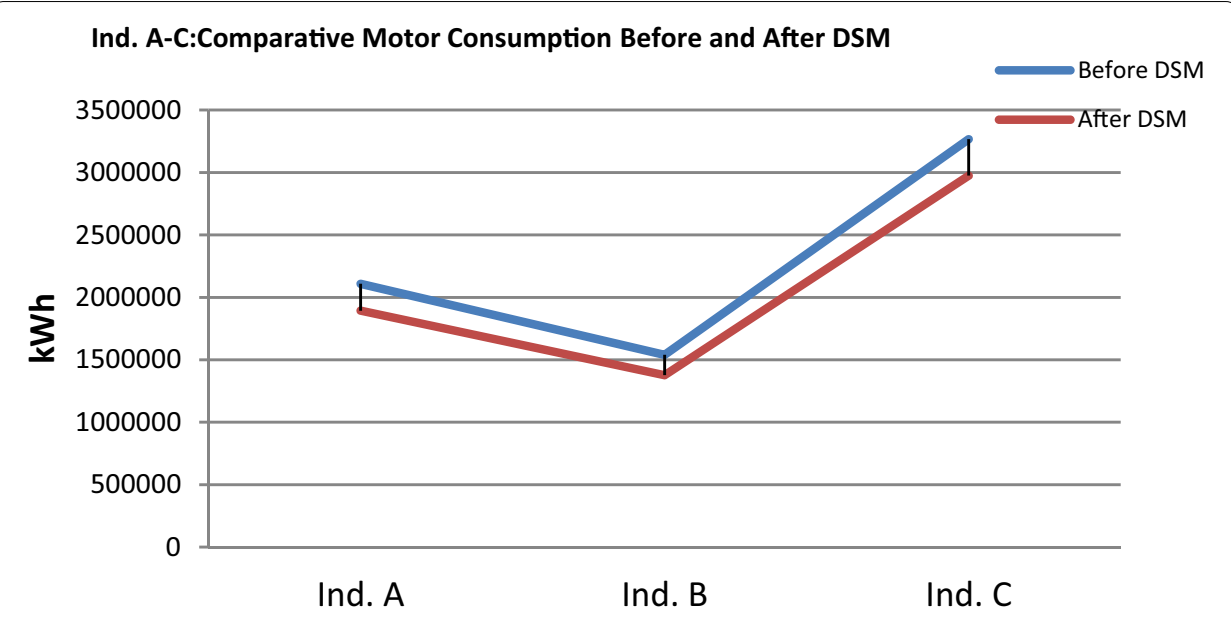

Fig. 4 Comparative of energy consumption by motors before and after application of DSM

Table 6 Overall investment and saving on electric motor

\begin{tabular}{llll}
\hline & Industry A & Industry B & Industry C \\
\hline Number of electric motors & 30 & 27 & 30 \\
Upgrade available (no of groups) & 7 & 10 & 6 \\
Total investment cost $(\$)$ & 80,809 & 63,446 & 117,829 \\
Total installation cost $(\$)$ & 4291 & 3053 & 5380 \\
Total energy savings (kW h/yr) & $215,930.85$ & $163,231.34$ & $292,436.82$ \\
Total potential savings $(\$ / y r)$ & $31,094.04$ & $23,505.31$ & $42,110.9$ \\
Total payback time (Month) & 34 & 36 & 35 \\
\hline
\end{tabular}

Table 7 Lighting calculations for industry A-C

\begin{tabular}{|c|c|c|c|c|c|c|}
\hline Fixture & Rating & Lumen per bulb & Industry A & Industry B & Industry C & $\begin{array}{l}\text { Proposed } \\
\text { retrofitting solution }\end{array}$ \\
\hline Florescent & 400 & 2300 & 360 & 300 & 330 & $\begin{array}{l}\text { LED tube of } 20 \mathrm{~W} \text { with } \\
2500 \mathrm{ml}\end{array}$ \\
\hline Incandescent 1 & 100 & 1750 & - & 150 & 4 & $\begin{array}{l}\text { CFL of } 30 \mathrm{~W} \text { with } \\
2100 \mathrm{ml}\end{array}$ \\
\hline Incandescent 2 & 200 & 3500 & 24 & - & 28 & $\begin{array}{l}\text { CFL of } 60 \text { W with } \\
4200 \mathrm{ml}\end{array}$ \\
\hline Incandescent 3 & 250 & 4875 & 15 & - & - & $\begin{array}{l}\text { CFL of } 90 \mathrm{~W} \text { with } \\
6300 \mathrm{ml}\end{array}$ \\
\hline Halogen & 400 & 8000 & 64 & 80 & 60 & $\begin{array}{l}\text { LED flood light } 100 \mathrm{~W} \\
\text { with } 8000 \mathrm{ml}\end{array}$ \\
\hline $\begin{array}{l}\text { Consumption before } \\
\text { DSM (kW h) }\end{array}$ & & & 202,620 & 236,400 & 181,800 & \\
\hline $\begin{array}{l}\text { Consumption after } \\
\text { DSM (kW h) }\end{array}$ & & & 68,940 & 75,240 & 61,326 & \\
\hline Savings (kW h) & & & 85,920 & 161,160 & 120,474 & \\
\hline
\end{tabular}


Table 8 Overall investment and saving on lighting fixtures

\begin{tabular}{llll}
\hline & Industry A & Industry B & Industry C \\
\hline Total investment cost $(\$)$ & $17,511.9$ & $20,278.5$ & 15,994 \\
Total installation cost $(\$)$ & 890 & 1000 & 800 \\
Total energy savings $(\mathrm{kW} / \mathrm{h} / \mathrm{r})$ & 133,680 & 161,160 & 120,474 \\
Total potential savings $(\$ / \mathrm{yr})$ & $19,249.92$ & $23,207.04$ & $17,348.26$ \\
Total payback time $($ Month) & 12 & 11 & 12 \\
\hline
\end{tabular}

\section{Green house gases emission}

The benefit of the DSM application was quantified in terms of carbon emission reduction, i.e. how much of $\mathrm{CO}_{2}$ would be saved by reducing the energy consumptions of the industries. The $\mathrm{CO}_{2}$ emissions reductions for the industries are estimated using countries regional emission rate. The regional emission rate for Nigeria is given as $1 \mathrm{~kW} \mathrm{~h}$ of energy to $0.404 \mathrm{~kg} \mathrm{CO}_{2}$. This was used to estimate the amount of $\mathrm{CO}_{2}$ emission for each of the industries before and after DSM application and the result is presented in Table 11.

It is revealed from the table that $159,471.2 \mathrm{~kg}, 139,598.7 \mathrm{~kg}$ and $186,696.4 \mathrm{~kg}$ of $\mathrm{CO}_{2}$ emission can be saved from industries A, B and C, respectively.

\section{Policy recommendation based on the study}

Following the results obtained from the walk through energy audit exercise, the retrofitting results presented in the manuscript as well as the personal onsite observations aim at identifying the bad practices and inefficient use of electrical energy in food and beverage industries in Nigeria, recommendations which could go into policy documents are proposed. This could enhance energy conservation, improve efficient utilizations of available energy resources and minimize energy waste without compromising the comfort of staff and quality of production in food and beverage industries. The specific recommendations are summarized as follows:

Table 9 Energy consumption in each of the 3 industries before and after DSM solution

\begin{tabular}{lllll}
\hline & Rating (W) & Industry A & Industry B & Industry C \\
\hline Computer (CPU + Monitor) & 300 & 64 & 20 & 58 \\
Annual energy consumption before DSM (kW h/yr) & & 57,600 & 27,000 & 62,820 \\
Annual energy consumption after DSM (kW h/yr) & 12,480 & 5850 & 13,611 \\
Savings in energy (kW h/yr) & 45,120 & 21,150 & 49,209 \\
\hline
\end{tabular}

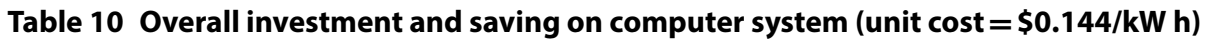

\begin{tabular}{llll}
\hline & Industry A & Industry B & Industry C \\
\hline Total investment cost (\$) & 30,080 & 9400 & 27,260 \\
Total potential savings (\$) & 6497 & 3046 & 7086 \\
Total payback time (Month) & 56 & 37 & 46 \\
\hline
\end{tabular}



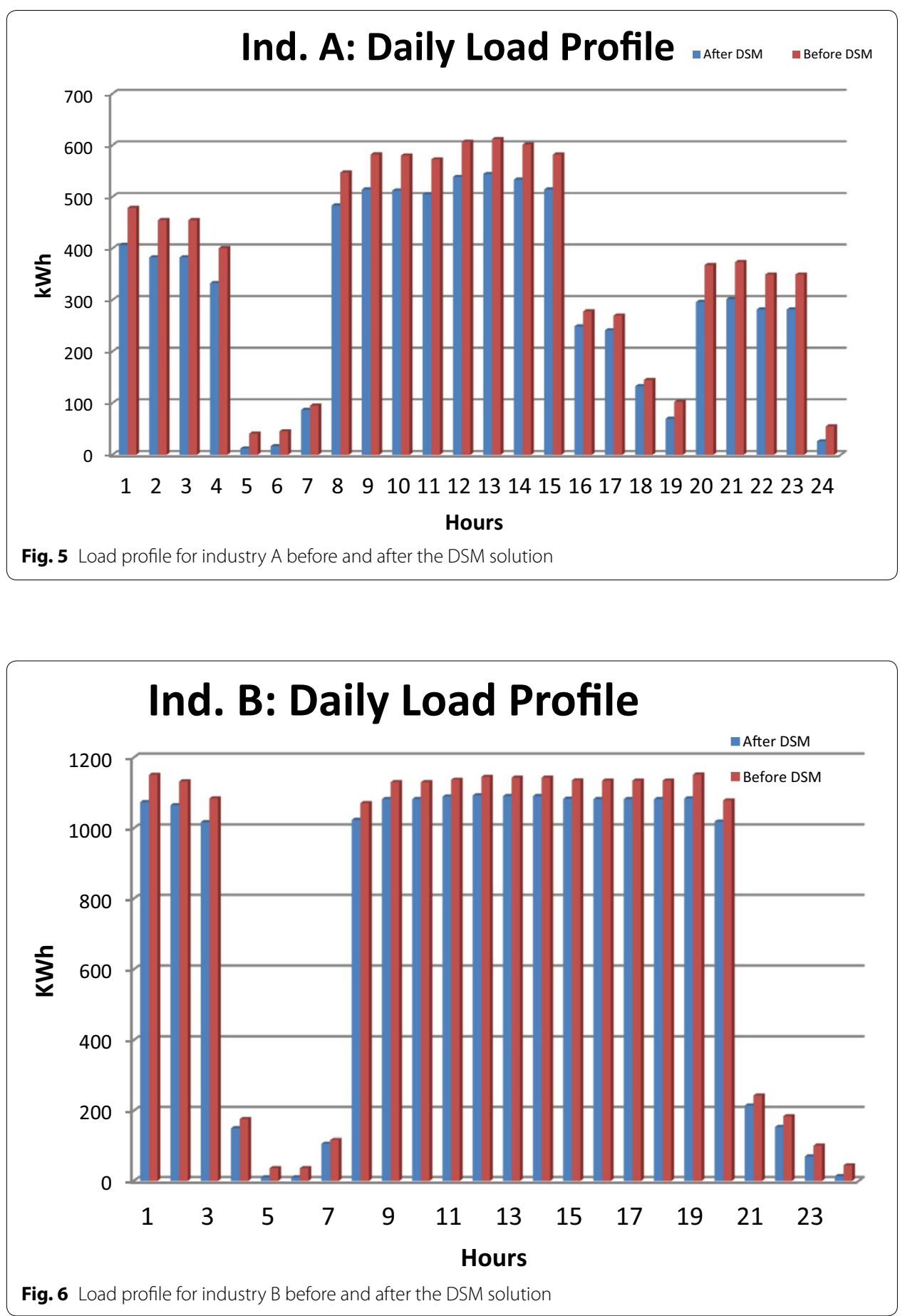

- There should be efficient use of energy without jeopardizing the provision of comfortable, secure environment for the food and beverage industry in Nigeria.

- Food and beverage industries should set aside expenditures for provision of clean and environmentally friendly energy solutions over a pre-determined period of time to allow for gradual transition into energy efficient devices. 


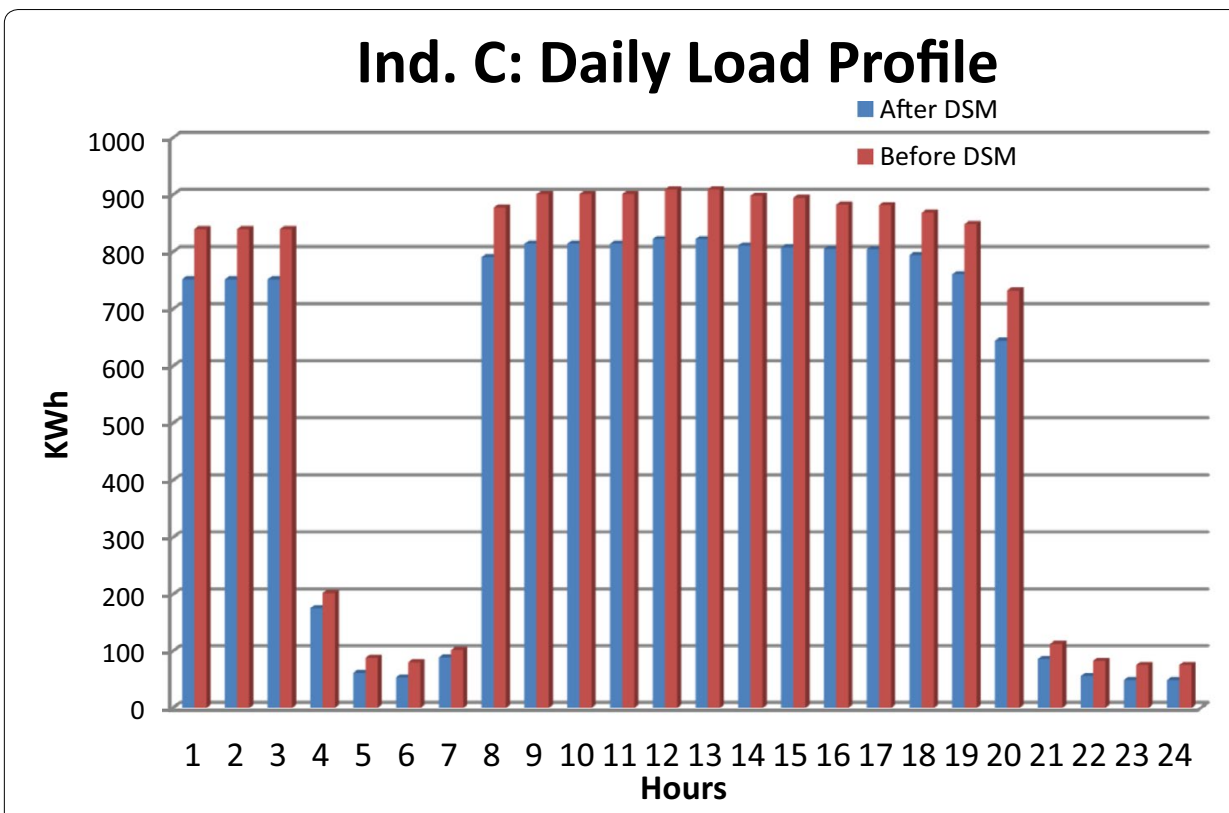

Fig. 7 Load profile for industry C before and after the DSM solution

Table 11 Comparison of $\mathrm{CO}_{2}\left(\mathrm{~kg} / \mathrm{CO}_{2}\right)$ emission before and after the DSM application

\begin{tabular}{llll}
\hline & Ind. A & Ind. B & Ind. C \\
\hline Before DSM & $957,498.1$ & $728,829.6$ & $1,419,112$ \\
After DSM & $798,026.9$ & $589,230.9$ & $1,232,415$ \\
CO $_{2}$ Savings & $159,471.2$ & $139,598.7$ & $186,696.4$ \\
\hline
\end{tabular}

- There should be guidelines and practices geared towards significant reduction of energy consumption in food and beverage companies.

- A unit should be set up for the purpose of carrying out research activities within the food and beverage industries towards incorporation energy-efficient technology in the design and operation of food and beverage industry.

- The companies should continuously embark on energy solutions which support significant reduction of greenhouse gas (GHG) emissions. The reduction in GHG shall be encouraged in terms of carbon credit.

- Energy use patterns of food and beverage industries should be continuously monitored by the relevant electricity utility companies to ensure adherence to energy efficient compliant.

- The use of variable speed drive should be encouraged over fixed speed drive, and power factor improvement technologies shall be employed to improve the energy utilizations of the industries.

- All the rewound motor should be replaced with a super-efficient motor as there is efficiency loss of about $3-7 \%$ for electric motors are rewound which could reduce the overall energy consumption efficiency of the companies. 
- Use of proper choice and removal of unnecessary lighting fixtures which would reduce electrical energy utilization should be ensured at all times.

- Training and awareness campaign for both the staff and management on the importance of energy efficiency should be conducted from time to time.

\section{Implementation strategies to achieving the recommendations}

In order to achieve the set recommendations by the food and beverages industries, strategies in form of a roadmap could be adopted on short-term, medium-term and longterm basis. In this way, energy efficiency and subsequent reduction in GHG in the food and beverage industry could be achieved.

\section{Short-term strategies}

- Creation of databank on energy consumption pattern of various units and department within the food and beverage industries.

- Provision of quality and relevant information on proven practices for energy demand side management within the food and beverage industries.

- Strengthening company framework for promotion of demand side energy management and its efficient utilization.

- Establishing energy conservation and efficiency benchmarking for staff within the companies.

- Embarking on education and awareness programmes as well as energy-efficient publication for both the staff and management on the need to be energy efficient conscious within the food and beverage companies.

- Strengthening culture of energy use efficiency through deployment of energy-saving devices.

- Introducing framework for energy efficient auditing in units and departments within the companies.

\section{Medium-term strategies}

- Rigorous review, improvement and continuation of short-term strategies.

- Identification and assessment of energy-saving opportunities through appropriate benchmarking and standardization through demand side management techniques.

- Enforcement of appropriate legislation on energy efficient system.

- Implementation and monitoring compliance with energy conservation and energy efficient standards.

- Integration of passive design features and systems for capturing climatic conditions within food and beverages industries for energy efficiency and conservation. 


\section{Long-term strategies}

- Rigorous review, improvement and continuation of medium term strategies.

- The use of timers and occupancy sensors that automatically turn off lights in all units and department within the food and beverage industries.

- Use of heaters with thermostat in all heating devices.

- Replacing all rewound motors with new super-efficient motors.

- Replacing all inefficient lighting fixtures with that of efficient devices in all offices and departments.

- Replacing all inefficient old computer system with the new more efficient ones.

\section{Conclusions}

The opportunities for reducing electrical energy consumption and the emission of $\mathrm{CO}_{2}$ in order to improve the environment and electrical energy utilization in food and beverage industries have been studied. From the study the following were concluded:

1. Application of DSM solution by retrofitting standard motors with super-efficient motors, retrofitting existing lighting fixture with energy efficient ones and upgrading the computer system will reduce the overall electrical energy consumption by $17 \%$, $20 \%$ and $14 \%$ for industries A, B and C, respectively.

2. This will result into overall $\mathrm{CO}_{2}$ emission reduction of $159,471.2 \mathrm{~kg} \mathrm{CO}_{2}, 139,598.7 \mathrm{~kg}$ $\mathrm{CO}_{2}$ and $186,696.4 \mathrm{~kg} \mathrm{CO}$ in each of the industries, respectively.

3. Retrofitting of standard motors with super-efficient motor will save each industry with $215,930.85 \mathrm{~kW}$ h, 163,231.34 kW h and 292,436.82 kW of energy per annum, which amount to saving electricity bill by $\$ 31,094, \$ 23,505$ and $\$ 421,111$ in industries A, B and C, respectively. The corresponding payback time for this practice is 34 , 36 and 35 months, respectively.

4. Retrofitting of existing lighting fixture with energy-efficient bulbs such as LED tubes, LED flood light and CFL will save each industry with 133,680 kW h, 161,160 kW h and $120,474 \mathrm{~kW}$ h of energy per annum, which amount to saving electricity bill by $\$ 19,249.92, \$ 23,207.04$ and $\$ 17,348.26$ in industries A, B and C, respectively. The corresponding payback time for this practice is 12,11 and 12 months, respectively.

5. Retrofitting of existing computers (monitor and CPU) with laptop computers will save each industry with 45,120 kW h, 21,150 kW h and 49,250 kW h of energy per annum, which amount to saving electricity bill by $\$ 6497, \$ 3046$ and $\$ 7092$ in industries A, B and C, respectively. The corresponding payback time for this practice is 56 , 37 and 46 months, respectively.

\footnotetext{
Abbreviations

DSM: Demand side management; GHG: Greenhouse gas; $\mathrm{CO}_{2}$ : Carbon IV oxide; GDP: Gross domestic product; NFBI: Nigerian food and beverage industry; IEC: International Electrotechnical Commission; WSU: Washington State University; LED: Light emitting diode; CPU: Central processing unit; E: Energy consumption; hp: Horsepower; $H_{\mathrm{op}}$ : Operating hours; $\eta$ : Motor efficiency; $C_{\mathrm{u}}$ : unit energy costs; PP: Premium price; IC: Installation cost; AS: Annual dollar savings; UR: Utility rebate; $\mathrm{CH}_{4}$ : Methane; EM: Emmission; GE: Total electricity consumption; D: Annual diesel consumption.
}

Acknowledgements

The authors want to thank the University of Ibadan for the conducive environment to conduct the research. 


\section{Authors' contributions}

A.S Ogunjuyibe, T.R Ayodele and SM Ogunmuyiwa conducted energy walkthrough audit on the selected food and beverages industries. T.R Ayodele and SM Ogunmuyiwa performed the analysis of the data. The analysis was crosschecked for correctness by A.S Ogunjuyibe. All the authors drafted, read and approve the manuscript.

\section{Funding}

Not applicable.

Availability of data and materials

The datasets used and/or analysed during the current study are available from the corresponding author on reasonable request.

\section{Competing interests}

The authors declare that they have no competing interests.

Received: 11 February 2020 Accepted: 6 May 2020

Published online: 24 May 2020

\section{References}

1. Aghajani G, Ghadimi N (2018) Multi-objective energy management in a micro-grid. Energy Rep 4:218-225

2. Alam M, Zou PXW, Sanjayan J, Stewart R, Sahin O, Bertone E, Wilson J (2016) Guidelines for building energy efficiency retrofitting. In: Sustainability in public works conference, pp 1-14

3. Alhorr Y, Eliskandarani E, Elsarrag E (2014) Approaches to reducing carbon dioxide emissions in the built environment: low carbon cities. Int J Sustain Built Environ 3:167-178

4. Ayodele TR, Ogunjuyigbe ASO, Ogunmuyiwa SM, Ojo O (2016) Determination of electrical energy use index for two selected Nigerian food and beverages industries. In: IEEE PES power Africa conference, Zambia pp 36-40

5. B.P-Energy-data (2014) The world energy demand 2014. www.bp.com/en/global/corporate/about-bp/energ y-economics/statistical-review-of-world-energy

6. Biswas WK (2014) Carbon footprint and embodied energy consumption assessment of building construction works in western Australia. Int J Sustain Built Environ 3:179-186

7. Bull J, Gupta A, Mumovic D, Kimpian J (2014) Life cycle cost and carbon footprint of energy efficient refurbishments to 20th century UK school buildings. Int J Sustain Built Environ 3:1-17

8. Dincer I, Midilli A (2014) Energy conservation. Springer, Switzerland

9. EIA (2016) Industrial energy consumption. U.S. Energy Information Administration/International Energy Outlook 2016, vol 7, pp. 115-126. https://www.eia.gov/outlooks/ieo/pdf/industrial.pdf

10. Eissa MM (2018) First time real time incentive demand response program in smart grid with "i-Energy" management system with different resources. Appl Energy 212:607-621

11. Escobedo A, Briceno S et al (2013) Energy consumption and GHG emission scenarios of a University Campus in Mexico. Energy Sustain Dev 18:49-57. https://doi.org/10.1016/j.esd.2013.10.005

12. Garcia A, Szklo AS et al (2007) Energy-efficiency standards for electric motors in Brazilian industry. Energy Policy 35:3424-3439

13. Ghiasi M (2019) Detailed study, multi-objective optimization, and design of an ACDC smart microgrid with hybrid renewable energy resources. Energy. https://doi.org/10.1016/j.energy.2018.12.083

14. Gopi S, Kumar N (2014) Energy audit as a tool for improving system efficiency in industrial sector. J Eng Res Appl 4(6):06-11

15. Goshwe Y, Kureve T (2012) Industrial energy management opportunities in Nigeria: a case study of energy audit of VIK Industries Nigeria, Ltd., vol 13, p 1. http://www.akamaiuniversity.us/PJST.htm

16. Ikedi CU, Okoroh MI (2015) Monitoring results of $\mathrm{CO}_{2}$ avoidance with an $8.5 \mathrm{~kW}$ h solar electric generator integrated in a high rise commercial building in UK. Int J Sustain Built Environ 4:189-201

17. ISCC (2011) GHG emissions calculation methodology and GHG audit. Internation sustainability and carbon certification (ISCC) V 2.3-EU

18. Khan I (2019) Energy-saving behaviour as a demand-side management strategy in the developing world: the case of Bangladesh. Int J Energy Environ Eng 10:493-510

19. Luther MB, Rajagopalan P (2014) Defining and developing an energy retrofitting approach. J Green Build 9(3):151-162

20. Martin N, Anglani N et al (2000) Opportunities to improve energy efficiency and reduce greenhouse gas emissions in the U.S. Pulp and Paper Industry. Environmental Energy DE-AC03-76SF00098

21. McCoy GA, Douglass JG (2000) Energy management for motor driven system. Department of Energy (DOE), Washington

22. Nan S, Zhou M, Li G (2018) Optimal residential community demand response scheduling in smart grid. Appl Energy 210:1280-1289

23. NBS (2014) Nigerian manufacturing sector sumary report 2010-2013. National Bureau of Statistics, pp 1-35

24. Ogunjuyigbe ASO, Ayodele TR, Akinola OA (2016) Optimal allocation and sizing of PV/wind/split-diesel/battery hybrid energy system for minimizing life cycle cost, carbon emission and dump energy of remote residential building. Appl Energy 171:153-171

25. Ogunjuyigbe ASO, Ayodele TR, Akinola OA (2017) User satisfaction-induced demand side load management in residential buildings with user budget constraint. Appl Energy 187:352-366 
26. Ogunjuyigbe ASO, Ayodele TR, Munda JL (2019) The impact of rewinding on the performance characteristics of three phase induction machine. In: IEEE Canadian conference of electrical and computer engineering (CCECE), Canada, pp 1-5

27. Ogunjuyigbe ASO, Ayodele TR, Ogunmuyiwa SM (2015) Improving electrical energy utilization in some selected nigerian food and beverage industries. Sustain Energy Technol Assess 12:38-45

28. Ogunjuyigbe ASO, Ayodele TR, Oladimeji OE (2016) Management of loads in residential buildings installed with PV system under intermittent solar irradiation using mixed integer linear programming. Energy Build 130:253-271

29. Olabisi P, Akinbulire B (2014) Techno-economic and environmental evaluation of demand side management techniques for rural electrification in Ibadan, Nigeria. Int J Energy Eng Environ 5:132

30. Oladokun MG, Odesola IA (2016) Household energy consumption and carbon emissions for sustainable cities—a critical review of modelling approaches. Int I Sustain Built Environ 5(2):1-17

31. Paradis R (2020) Retrofitting existing building to improve sustainability and energy performance, pp 1-7. www.nibs. org/. Accessed 26 Apr 2020

32. Radwan AF, Hanafy AA, Elhelw M, El-Sayed AEHA (2016) Retrofitting of existing buildings to achieve better energyefficiency in commercial building case study: hospital in Egypt. Alex Eng J 55:3061-3071

33. Russel C (2005) Strategic industrial energy efficiency: reduce expenses, build revenues, and control risk. Energy Eng 102(3):7-27

34. Satish S (2014) The growing need of demand-side management. Energy programmes SancoGlobals

35. Sola AVH, Xavier AAP (2007) Organizational human factors as barriers to energy efficiency in electrical motors systems in industry. Energy Policy 35(11):5784-5794

36. Štreimikienè D (2014) Residential energy consumption trends, main drivers and policies in Lithuania. Renew Sustain Energy Rev 35:285-293

37. Walzberg J, Dandres T, Merveille N, Cheriet M, Samson R (2019) Accounting for fluctuating demand in the life cycle assessments of residential electricity consumption and demand side management strategies. $J$ Clean Prod 240:118251-118284

\section{Publisher's Note}

Springer Nature remains neutral with regard to jurisdictional claims in published maps and institutional affiliations.

\section{Submit your manuscript to a SpringerOpen ${ }^{\odot}$ journal and benefit from:}

- Convenient online submission

- Rigorous peer review

- Open access: articles freely available online

- High visibility within the field

- Retaining the copyright to your article

Submit your next manuscript at $\boldsymbol{\nabla}$ springeropen.com 